\title{
Induction of Exaggerated Cytokine Production in Human Peripheral Blood Mononuclear Cells by a Recombinant SARS-CoV-2 Spike Glycoprotein S1 and Its Inhibition by Dexamethasone
}

\author{
Olumayokun A. Olajide $\mathbb{B},{ }^{1,3}$ Victoria U. Iwuanyanwu, ${ }^{1}$ Izabela Lepiarz-Raba, ${ }^{2}$ and \\ Alaa A. Al-Hindawi ${ }^{1}$
}

(Received February 14, 2021; accepted April, 3 2021)

Abstract-An understanding of the pathological inflammatory mechanisms involved in SARS-CoV-2 virus infection is necessary in order to discover new molecular pharmacological targets for SARS-CoV-2 cytokine storm. In this study, the effects of a recombinant SARS-CoV-2 spike glycoprotein S1 was investigated in human peripheral blood mononuclear cells (PBMCs). Stimulation of PBMCs with spike glycoprotein S1 $(100 \mathrm{ng} / \mathrm{mL})$ resulted in significant elevation in the production of TNF $\alpha$, IL-6, IL-1 $\beta$ and IL-8. However, pretreatment with dexamethasone $(100 \mathrm{nM})$ caused significant reduction in the release of these cytokines. Further experiments revealed that $\mathrm{S} 1$ stimulation of PBMCs increased phosphorylation of NF- $k B$ p 65 and $I \kappa B \alpha$, and $I \kappa B \alpha$ degradation. DNA binding of NF- $k B$ p65 was also significantly increased following stimulation with spike glycoprotein S1. Treatment of PBMCs with dexamethasone $(100 \mathrm{nM})$ or BAY11-7082 $(1 \mu \mathrm{M})$ resulted in inhibition of spike glycoprotein S1-induced NF-KB activation. Activation of p38 MAPK by S1 was blocked in the presence of dexamethasone and SKF 86002. CRID3, but not dexamethasone pre-treatment, produced significant inhibition of S1-induced activation of NLRP3/caspase-1. Further experiments revealed that S1-induced increase in the production of TNF $\alpha$, IL-6, IL$1 \beta$ and IL-8 was reduced in the presence of BAY11-7082 and SKF 86002, while CRID3 pretreatment resulted in the reduction of IL- $1 \beta$ production. These results suggest that SARSCoV-2 spike glycoprotein S1 stimulated PBMCs to release pro-inflammatory cytokines through mechanisms involving activation of NF-KB, p38 MAPK and NLRP3 inflammasome.

\footnotetext{
${ }^{1}$ Department of Pharmacy, School of Applied Sciences, University of Huddersfield, Queensgate, Huddersfield, HD1 3DH, UK

${ }^{2}$ Present Address: BRAINCITY-EMBL-Nencki Center of Excellence for Neuronal Plasticity and Brain Disorders, Nencki Institute of Experimental Biology, Warsaw, Poland

${ }^{3}$ To whom correspondence should be addressed at Department of Pharmacy, School of Applied Sciences, University of Huddersfield, Queensgate, Huddersfield, HD1 3DH, UK. E-mail: o.a.olajide@hud.ac.uk
} 
It is proposed that the clinical benefits of dexamethasone in COVID-19 are possibly due to its anti-inflammatory activity in reducing SARS-CoV-2 cytokine storm.

KEY WORDS: SARS-CoV-2 cytokine storm; SARS-CoV-2 spike glycoprotein S1; inflammation; $\mathrm{NF}_{-\mathrm{K}} \mathrm{B}$; PBMCs.

\section{INTRODUCTION}

The severe acute respiratory syndrome coronavirus 2 (SARS-CoV-2) emerged in China in December 2019. Since the first report of its emergence, there has been a global spread of the infection accompanied by widespread appearance of coronavirus disease 2019 (COVID-19) [1, 2]. As of 21st March 2021, there were 122,536,880 confirmed cumulative cases and 2,703,780 confirmed deaths globally [3].

At the onset of infection, symptoms of illness caused by SARS-CoV-2 infection (COVID-19) are fever, cough, myalgia or fatigue, headache, dyspnoea and pneumonia, while the major complications identified are acute respiratory distress syndrome, cardiac injury and secondary infection [4]. Among these symptoms and complications, end organ damage and acute respiratory distress syndrome (ARDS) have been suggested to be the leading causes of death in critically ill patients [5]. This is not surprising as studies have shown that excessive release of inflammatory mediators results in cytokine storm, which has been implicated in both ARDS and multi-organ failure [6-8].

Clinical evidence has proposed that the cytokine storm in COVID-19 involves a vicious cycle of inflammatory responses which are characterised by excessive release of pro-inflammatory cytokines including interleukin-1 (IL1), interleukin-6 (IL-6), interleukin-12 (IL-12), interferon gamma (IFN $\gamma$ ) and tumour necrosis factor (TNF $\alpha)$ which target lung tissues $[6,9,10]$. During the pulmonary phase of COVID-19, SARS-CoV-2 virus infects the upper and lower respiratory tracts using angiotensin-converting enzyme 2 (ACE2) as the receptor for host entry [8]. However, in the pro-inflammatory phase, SARS-CoV-2 activates the host's immune system to trigger both adaptive and innate immune responses [11-13]. The resulting macrophagemediated hyperactive immune response and stimulation of inflammatory cytokines have been shown to result in acute lung injury, ARDS, systemic inflammatory response syndrome (SIRS), shock and multi-organ dysfunction [14, 15].

Attachment, fusion and entry of the SARS-CoV-2 virus into the host's cells are facilitated by the spike glycoprotein which binds to the host ACE2 receptor [16, 17]. Studies have shown that in addition to facilitating its fusion to the cell membrane, the location of the spike glycoprotein on SARS-CoV-2 also makes it a direct target for host's immune responses [16]. Of the two sub-units of the spike glycoprotein (S1 and S2), the receptor-binding domain (RBD) of S1 is the main sub-unit of the spike protein for ACE2 binding. It is therefore proposed that the SARSCoV-2 glycoprotein S1 may be responsible for triggering exaggerated responses in immune cells to cause cytokine storm.

There is limited experimental data highlighting the mechanisms involved in exaggerated inflammatory responses in immune cells during SARS-CoV-2 cytokine storm. Furthermore, there is a need to develop cellular pharmacological models for investigating antiinflammatory drugs and novel compounds as adjuncts to treat immune cell-mediated cytokine storm in SARS-CoV2 infection.

In this study, we have evaluated the effects of stimulating human peripheral blood mononuclear cells (PBMCs) with a recombinant human SARS-CoV-2 spike glycoprotein S1. We have further evaluated the effects of the anti-inflammatory drug, dexamethasone on SARSCoV-2 spike glycoprotein S1-induced inflammation in PBMCs.

\section{MATERIALS AND METHODS}

\section{Materials}

Recombinant human coronavirus SARS-CoV-2 spike glycoprotein S1 (ab273068; Lots GR3356031-1 and 3353172-2; Accession MN908947) was purchased from Abcam. The protein was reconstituted in sterile water for functional studies. The following drugs were used: BAY11-7082 (Sigma), CRID3 sodium salt (Tocris), SKF 86002 dihydrochloride (Tocris) and dexamethasone (Sigma).

\section{Cell Culture}

Human peripheral blood mononuclear cells (hPBMCs) (Lonza Biosciences; Catalogue \#: 4W-270; Batch: 3038013) were isolated from peripheral blood by apheresis and density gradient separation. Frozen cells 
were thawed and transferred to a sterile centrifuge tube. Thereafter, warmed RPMI medium was added to the cells slowly, allowing gentle mixing. The cell suspension was then centrifuged at $400 \times \mathrm{g}$ for $10 \mathrm{~min}$. After centrifugation, supernatant was discarded and fresh warmed RPMI was added to the pellet. This was followed by another centrifugation at $400 \times \mathrm{g}$ for $10 \mathrm{~min}$. Supernatant was removed and cells were suspended in RPMI, counted and allowed to rest overnight.

\section{Production of Pro-inflammatory Cytokines}

Human PBMCs were seeded out in a 24-well plate at $5 \times 10^{4}$ cells $/ \mathrm{mL}$ and treated with spike glycoprotein S1 $(10,50$ and $100 \mathrm{ng} / \mathrm{mL})$ for $24 \mathrm{~h}$. Thereafter, medium was collected and centrifuged to obtain culture supernatants. Experiments were also carried out in cells pre-treated with dexamethasone $(1,10$ and $100 \mathrm{ng} / \mathrm{ml})$ for $1 \mathrm{~h}$ prior to stimulation with spike glycoprotein S1 $(100 \mathrm{ng} / \mathrm{ml})$ for a further $24 \mathrm{~h}$. Levels of TNF $\alpha$ in the supernatants were determined using human ELISA ${ }^{\mathrm{TM}}$ kit (Abcam). Concentrations of TNF $\alpha$ in supernatants were calculated from a human $\mathrm{TNF} \alpha$ standard curve, and the assay range was $15.63-1000 \mathrm{pg} / \mathrm{mL}$. Levels of IL-6 in supernatants were determined using human IL-6 ELISA kit (Abcam). The range for IL-6 detection was $7.8-500 \mathrm{pg} / \mathrm{mL}$. Similarly, levels of IL- $1 \beta$ were evaluated using human IL- $1 \beta$ ELISA kit (Abcam), with a range of detection of 14.06-900 pg/ $\mathrm{mL}$, while IL-8 production was evaluated using human IL8 ELISA kit (Thermo Scientific), with assay range of 2$250 \mathrm{pg} / \mathrm{mL}$.

\section{In-Cell Western (Cytoblot) Analysis}

The in-cell western (cytoblot) analysis is a proven method for the rapid quantification of proteins in cells $[18,19]$. PBMCs were seeded into a black 96-well plate at $5 \times 10^{4}$ cells $/ \mathrm{mL}$. At $70 \%$ confluence, cells were stimulated with spike glycoprotein S1 $(100 \mathrm{ng} / \mathrm{ml})$ for different periods. At the end of each experiment, cells were fixed with $8 \%$ paraformaldehyde solution $(100 \mu \mathrm{L})$ for $15 \mathrm{~min}$, followed by washing with PBS. The cells were then incubated with primary antibodies overnight at $4{ }^{\circ} \mathrm{C}$. The following antibodies were used: rabbit anti-phosphop65 (Cell Signalling Technology), rabbit anti-phospho-

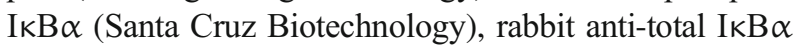
(Santa Cruz Biotechnology), rabbit anti-phospho-p38 (Cell Signalling Technology) and rabbit anti-NLRP3 (Abcam) antibodies. Thereafter, cells were washed with PBS and incubated with anti-rabbit HRP secondary antibody for $2 \mathrm{~h}$ at room temperature. Then, $100 \mu \mathrm{L}$ HRP substrate was added to each well and absorbance measured at $450 \mathrm{~nm}$ with a Tecan Infinite $M$ microplate reader. Readings were normalised with Janus Green normalisation stain (Abcam).

\section{NF-кB p65 Transcription Factor Binding Assay}

The NF- $\mathrm{kB}$ p65 transcription factor assay is a nonradioactive ELISA-based assay for evaluating DNA binding activity of NF- $\mathrm{KB}$ in nuclear extracts. PBMCs were seeded in a 6-well plate at a density of $4 \times 10^{4}$ cells $/ \mathrm{mL}$. The cells were then incubated with $100 \mathrm{ng} / \mathrm{mL}$ of spike glycoprotein S1 protein with or without dexamethasone $(100 \mathrm{nM})$ or the NF-KB inhibitor BAY11-7082 $(1 \mu \mathrm{M})$ for $60 \mathrm{~min}$. At the end of the incubation, nuclear extracts were prepared from the cells and subjected to NF- $\mathrm{KB}$ transcription factor binding assay according to the instructions of the manufacturer (Abcam).

\section{Caspase-Glo®1 Inflammasome Assay}

The caspase-Glo®1 inflammasome assay (Promega) was used to measure the activity of caspase- 1 directly in live cells or culture supernatants. PBMCs were seeded out in a 24-well plate at a density of $4 \times 10^{4}$ cells $/ \mathrm{mL}$ and pretreated with dexamethasone $(100 \mathrm{nM})$ or the NLRP3 inhibitor CRID3 $(1 \mu \mathrm{M})$ for $60 \mathrm{~min}$ prior to stimulation with spike glycoprotein S1 $(100 \mathrm{ng} / \mathrm{mL})$ for a further $6 \mathrm{~h}$. After stimulation, cell culture supernatants were collected and mixed with equal volume of Caspase-Glo® 1 reagent or Caspase-Glo ${ }^{\circledR} 1$ Reagent + YVAD-CHO $(1 \mu \mathrm{M})$ in a 96well plate. The contents of the wells were mixed using a plate shaker at $400 \mathrm{rpm}$ for $30 \mathrm{~s}$. The plate was then incubated at room temperature for $60 \mathrm{~min}$, followed by luminescent measurement of caspase-1 activity with a FLUOstar OPTIM reader (BMG LABTECH).

\section{Human NLRP3 ELISA}

PBMCs were seeded out into a 6-well plate and allowed to settle overnight. Thereafter, the cells were stimulated with spike glycoprotein $\mathrm{S} 1(100 \mathrm{ng} / \mathrm{mL})$ in the presence or absence of dexamethasone $(100 \mathrm{nM})$ or CRID3 $(1 \mu \mathrm{M})$ for $6 \mathrm{~h}$. Cell lysates were prepared by centrifugation at $2000 \times \mathrm{g}$ for $7 \mathrm{~min}$ at $4{ }^{\circ} \mathrm{C}$. The supernatant was discarded, and the cells washed in ice-cold PBS by centrifugation at $2000 \times \mathrm{g}$ for $7 \mathrm{~min}$ at $4{ }^{\circ} \mathrm{C}$. Thereafter, ice-cold lysis buffer was added to the cell pellet, followed by sonication for $30 \mathrm{~min}$, and centrifugation at $16000 \times \mathrm{g}$ for $20 \mathrm{~min}$ at $4{ }^{\circ} \mathrm{C}$. Supernatants were collected and analysed for levels of NLRP3 protein using human NLRP3 ELISA kit (Abcam), according to the manufacturer's instructions. 


\section{Effects of NF- $k \mathrm{~B}, \mathrm{p38}$ and NLRP3 Inhibitors on Cytokine Production}

PBMCs were seeded out in a 24-well plate at $5 \times 10^{4}$ cells $/ \mathrm{mL}$ and treated with BAY-11-7082 $(1 \mu \mathrm{M})$, CRDI3 $(1 \mu \mathrm{M})$ or the p38 MAPK inhibitor SKF $86002(1 \mu \mathrm{M})$. One hour later, cells were stimulated with S1 protein (100 $\mathrm{ng} / \mathrm{mL}$ ) for a further $24 \mathrm{~h}$. Culture media were collected and supernatants analysed for levels of TNF $\alpha$, IL-6, IL-1 $\beta$ and IL- 8 as described above.

\section{Statistical Analysis}

Data are expressed as mean \pm SEM for at least three independent experiments $(n=3)$ and analysed using oneway analysis of variance (ANOVA) with post-hoc Tukey's test. Statistical analysis was conducted using the GraphPad Prism software.

\section{RESULTS}

\section{Stimulation of PBMCs with Spike Protein S1 Resulted in Increased Production of TNF $\alpha$, IL-6, IL-1 $\beta$ and IL- 8}

Following incubation of PBMCs with the spike glycoprotein $\mathrm{S} 1(10 \mathrm{ng} / \mathrm{mL})$ for $24 \mathrm{~h}$, analyses of cell supernatants showed no significant $(p<0.05)$ increase in the release of TNF $\alpha$. On increasing the concentration of the spike glycoprotein to 50 and $100 \mathrm{ng} / \mathrm{mL}$, there was $\sim 10$ and $\sim 24$-fold increase in TNF $\alpha$ secretion, respectively (Fig. 1a). Similarly, analyses of supernatants for levels of IL-6 (Fig. 1b), IL-1 $\beta$ (Fig. 1c) and IL-8 (Fig. 1d) revealed that incubation with $10 \mathrm{ng} / \mathrm{mL}$ of the spike glycoprotein S1 did not induce significant elevation in the production of the cytokines, while significant $(p<0.05)$ increases were demonstrated in cells incubated with 50 and $100 \mathrm{ng} / \mathrm{mL}$ of the glycoprotein.

\section{Increased Production of Pro-inflammatory Mediators by S1 Is Reduced by Dexamethasone}

We next evaluated effects of dexamethasone $(1,10$ and $100 \mathrm{nM}$ ) on excessive production of pro-inflammatory cytokines in PBMCs stimulated with spike glycoprotein S1 $(100 \mathrm{ng} / \mathrm{mL})$ for $24 \mathrm{~h}$. Results in Fig. 2a show that pretreatment with $1 \mathrm{nM}$ of dexamethasone did not prevent S1induced increased production of TNF $\alpha$. On increasing the concentration of dexamethasone to $10 \mathrm{nM}$, there was a weak but insignificant $(p<0.05)$ reduction in TNF $\alpha$ production. However, on pre-treating the cells with $100 \mathrm{nM}$ of dexamethasone, a significant $(p<0.05)$ reduction in S1induced increased production of TNF $\alpha$ was observed.

Figure $2 \mathrm{~b}$ shows that the anti-inflammatory effect of dexamethasone on S1-induced exaggerated production of IL-6 in PBMCs was significantly reduced $(p<0.05)$ by pre-treatment with $100 \mathrm{nM}$, but not the lower concentrations ( 10 and $50 \mathrm{nM}$ ) of the drug. Furthermore, analyses of samples obtained from PBMCs pre-treated with dexamethasone $(1 \mathrm{nM})$ revealed no reduction in the production of IL$1 \beta$. However, pre-treatment with 10 and $100 \mathrm{nM}$ of the drug resulted in significant $(p<0.001)$ reduction in IL-1 $\beta$ production (Fig. 2c).

Similarly, stimulation of PBMCs with spike glycoprotein $\mathrm{S} 1(100 \mathrm{ng} / \mathrm{mL})$ for $24 \mathrm{~h}$ resulted in $\sim 14$-fold increase in the production of IL-8. This increase was not reduced by 1 and $10 \mathrm{nM}$ of dexamethasone. However, increasing the concentration to $100 \mathrm{nM}$ resulted in $\sim 59 \%$ production of IL-8, when compared to S1 stimulation alone (100\%) (Fig. 2d).

\section{Effects of Spike Glycoprotein S1 on NF-KB Activation in PBMCs}

Based on results showing that the spike glycoprotein protein S1 stimulated PBMCs to induce increased production of pro-inflammatory cytokines, we investigated the roles of NF- $\mathrm{kB}$ activation in these effects of the protein. Firstly, we used in cell western assays to evaluate the effects of S1 stimulation on protein expression of phospho-p65, phospho-IкB $\alpha$ and total IкB $\alpha$ in the presence and absence of dexamethasone and BAY-11-7082. Results in Fig. 3a show that following stimulation of PBMCs with $\mathrm{S} 1(100 \mathrm{ng} / \mathrm{mL})$ for $15 \mathrm{~min}$, there was $\sim 12.7$-fold increase $(p<0.001)$ in protein expression of phospho-p65. Pretreatment of PBMCs with dexamethasone $(100 \mathrm{nM})$ and BAY-11-7082 $(1 \mu \mathrm{M})$ for $60 \mathrm{~min}$ prior to stimulation with S1 resulted in significant $(p<0.05)$ inhibition of p65 phosphorylation. Similarly, significant $(p<0.001)$ spike protein S1-induced increase in phospho-IкB $\alpha$ and decrease in total IKB $\alpha$ protein levels were prevented by pretreatment with dexamethasone $(100 \mathrm{nM})$ and BAY-11$7082(1 \mu \mathrm{M})$ (Fig. 3b and c).

Based on our results showing that spike protein $\mathrm{S} 1$ activates the processes resulting in translocation of $\mathrm{NF}-\mathrm{KB}$ to the nucleus, we next asked whether the protein had any effect on DNA binding by NF-kB. Figure $3 \mathrm{~d}$ illustrates an increase in DNA binding of NF-KB following stimulation of PBMCs with S1 (100 $\mathrm{ng} / \mathrm{mL}$ ) for $60 \mathrm{~min}$, when compared with unstimulated cells. On the other hand, incubating the cells with 
a

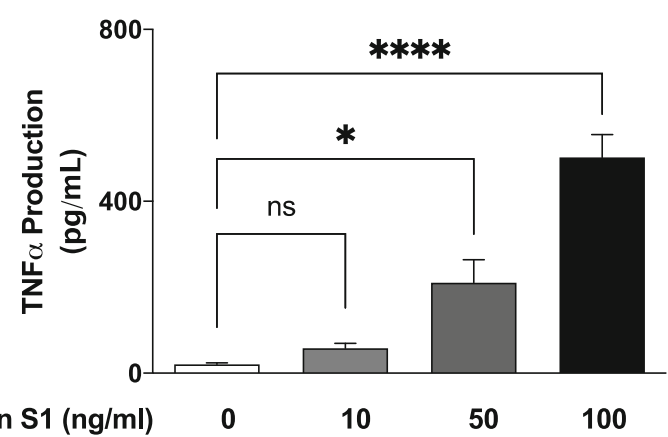

C

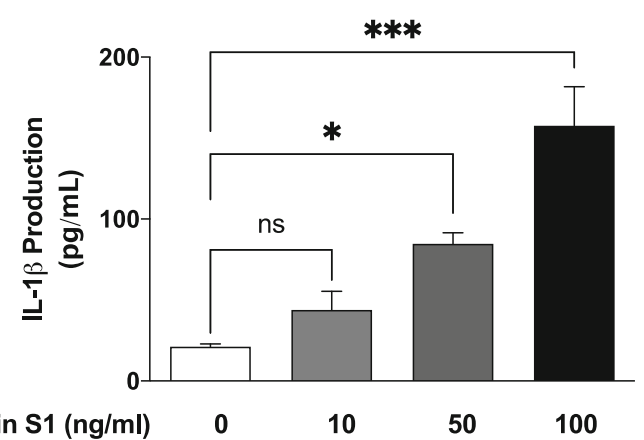

Spike Protein $\mathrm{S1}(\mathrm{ng} / \mathrm{ml})$ b

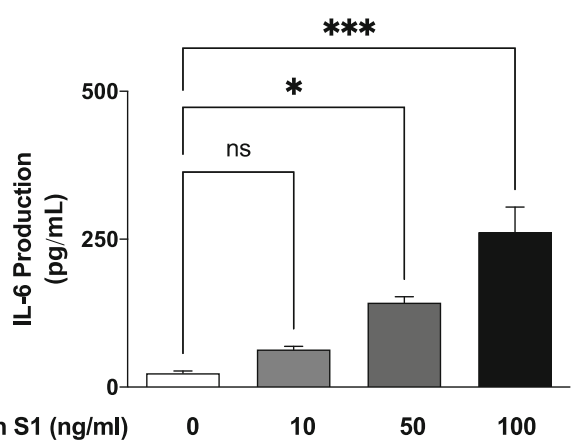

d

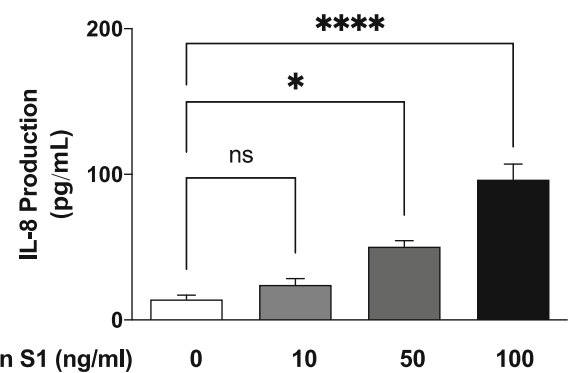

Fig. 1. Effects of spike glycoprotein $\mathrm{S} 1(10,50$ and $100 \mathrm{ng} / \mathrm{mL})$ stimulation on TNF $\alpha$ (a), IL-6 (b), IL-1 $\beta$ (c) and IL-8 (d) production in human PBMCs. Culture supernatants were collected following stimulation for $24 \mathrm{~h}$ and analysed using human ELISA kits for TNF $\alpha$, IL-6, IL-1 $\beta$ and IL- 8 . Values are mean \pm SEM for at least 3 independent experiments (ns: not significant; $* p<0.05 ; * * *<0.001$; $* * * *<0.0001$, compared with unstimulated control; one-way ANOVA with post-hoc Tukey's test).

either dexamethasone (100 nM) or BAY11-7082 (1 $\mu \mathrm{M})$ for $60 \mathrm{~min}$ prior to stimulation with S1 resulted in significant $(p<0.001)$ inhibition in DNA binding by NF- $\mathrm{kB}$. These results indicate that pre-treating PBMCs with dexamethasone and BAY11-7082 inhibited DNA binding by $\sim 46$ and $\sim 60 \%$, respectively, when compared with cells stimulated S1 alone.

\section{Activation of p38 MAPK by Spike Glycoprotein S1}

In-cell western blot analyses revealed that stimulation of PBMCs with spike glycoprotein $\mathrm{S} 1(100 \mathrm{ng} / \mathrm{mL})$ for 60 min resulted in a significant $(p<0.0001)$ increase in phospho-p38 protein, when compared with unstimulated cells. On the other hand, when compared with spike glycoprotein S1 stimulation alone (100\% expression), pretreatment with dexamethasone $(100 \mathrm{nM})$ resulted in $61.9 \%$ expression of phospho-p38 protein, while expression in cells pre-treated with SKF $86002(1 \mu \mathrm{M})$ was $27.2 \%$ (Fig. 4).

\section{NLRP3 Inflammasome/Caspase-1 Was Activated by S1}

We previously showed that spike glycoprotein S1 induced an increase in IL-1 $\beta$ production in PBMCs. We next asked whether activation of NLRP3 inflammasome/ caspase-1 pathway contributed to this effect. Results of ELISA and in-cell western assay in Fig. 5a and b show that following stimulation with $\mathrm{S} 1(100 \mathrm{ng} / \mathrm{ml})$ for $6 \mathrm{~h}$, there was a significant $(p<0.01)$ increase in protein levels of NLRP3, in comparison with untreated control cells. It was further shown that S1-induced elevation of NLRP3 was significantly reduced in the presence of CRID3 (1 $\mu \mathrm{M})$, while pre-treatment with dexamethasone $(100 \mathrm{nM})$ produced a slight and insignificant $(p<0.05)$ reduction in S1-induced increase in NLRP3 protein. Similarly, caspse-1 activity was increased in comparison with untreated PBMCs following stimulation with spike glycoprotein S1 $(100 \mathrm{ng} / \mathrm{ml})$. On pre-treating cells with CRID3 $(1 \mu \mathrm{M})$ prior to S1 stimulation, a reduction in caspase-1 activity was observed. Interestingly, pre-treatment with 


\section{a}

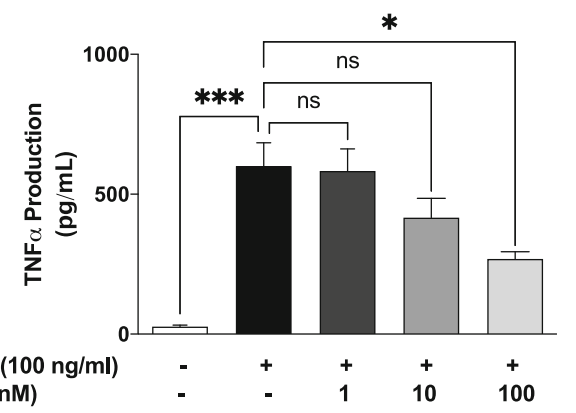

C

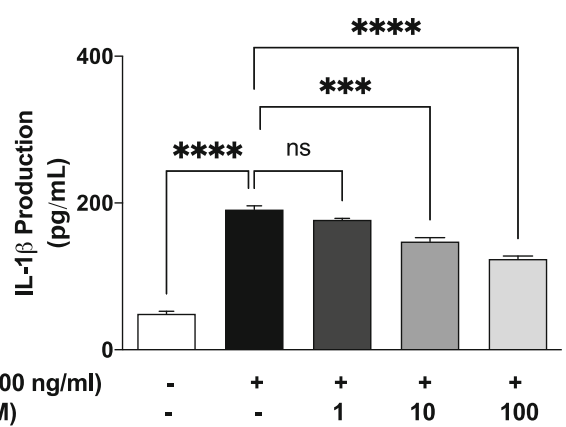

Spike Protein S1 (100 ng/ml) Dexamethasone (nM) b

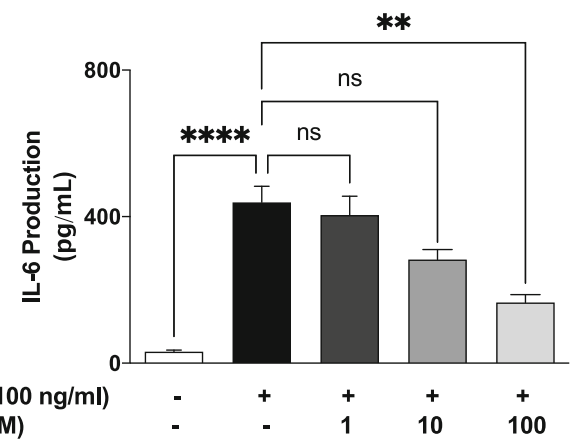

Spike Protein $\mathrm{S} 1(100 \mathrm{ng} / \mathrm{ml})$ Dexamethasone (nM)

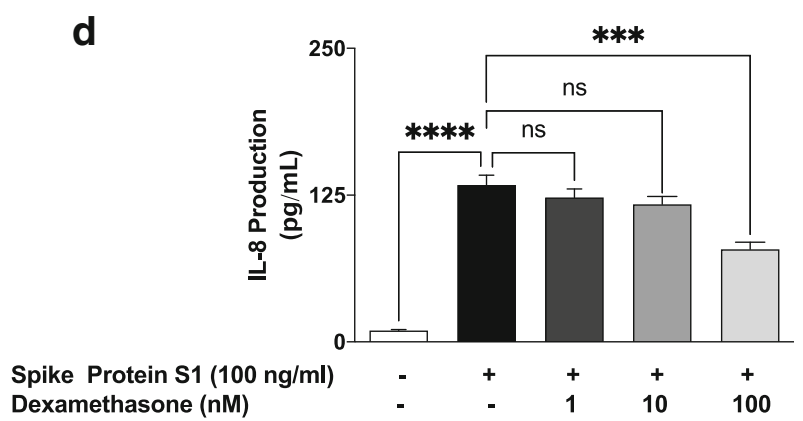

Fig. 2. Effects of pre-treatment with dexamethasone (1, 10 and $100 \mathrm{nM}$ ) on increased TNF $\alpha$ (a), IL-6 (b), IL-1 $\beta$ (c) and IL-8 (d) production induced by spike glycoprotein S1 (100 ng/mL) in human PBMCs. Culture supernatants were collected following stimulation for $24 \mathrm{~h}$ and analysed using human ELISA kits for $\mathrm{TNF} \alpha$, IL-6, IL-1 $\beta$ and IL-8. Values are mean \pm SEM for at least 3 independent experiments (ns: not significant; $* p<0.05 ; * * p<0.01 ; * * * p<0.001 ; * * * * p$ $<0.0001$, compared with unstimulated control or spike glycoprotein S1 stimulation; one-way ANOVA with post-hoc Tukey's test).

dexamethasone did not have significant effect on S1induced increase in caspase-1 activity (Fig. 5c).

\section{Effects of BAY11-7082, SKF 86002 and CRID3 on SARS-CoV-2 Spike Protein S1-Induced Increased Production of Inflammatory Cytokines}

Having demonstrated that spike glycoprotein S1 activated NF- $\mathrm{KB}, \mathrm{p} 38$ and NLRP3 in PBMCs, we were then interested in evaluating the direct roles of these targets in S1-induced exaggerated production of proinflammatory cytokines. Results in Fig. 6 show that in the presence of BAY11-7082 $(1 \mu \mathrm{M})$, there were significant reductions in increased production of TNF $\alpha$, IL-6, IL-1 $\beta$ and IL-8 in spike glycoprotein S1 $(100 \mathrm{ng} / \mathrm{mL})$ stimulated PBMCs. Similar reductions were observed when cells were pre-treated with SKF $86002(1 \mu \mathrm{M})$ prior to S1 stimulation. However, CRID3 $(1 \mu \mathrm{M})$ produced significant $(p<0.01)$ reduction in IL-1 $\beta$ production (Fig. 6c), while having no effect on the release of TNF $\alpha$, IL-6 and IL-8 (Fig. 6a, b, and d).

\section{DISCUSSION}

The cytokine storm is now established to be a major contributor to the fatalities of COVID-19. Consequently, an understanding of the pathological inflammatory mechanisms involved in SARS-CoV-2 virus infection is necessary in order to discover new molecular pharmacological targets. This study demonstrated that stimulation of human PBMCs with a recombinant spike glycoprotein S1 for $24 \mathrm{~h}$ resulted in significant release of pro-inflammatory cytokines TNF $\alpha$, IL-6, IL-1 $\beta$ and IL-8. These results appear to explain the increased serum levels of inflammatory cytokines which were widely reported in patients with severe COVID-19. It is therefore proposed that SARS-CoV-2 infection results in spike protein-mediated activation of monocytes, macrophages and dendritic cells, resulting in positive feedback involving dysregulated production of cytokines.

Several clinical studies have reported that hyperinflammation, accompanied by increased serum levels of pro-inflammatory cytokines and chemokines, is associated with disease severity and death in COVID-19 

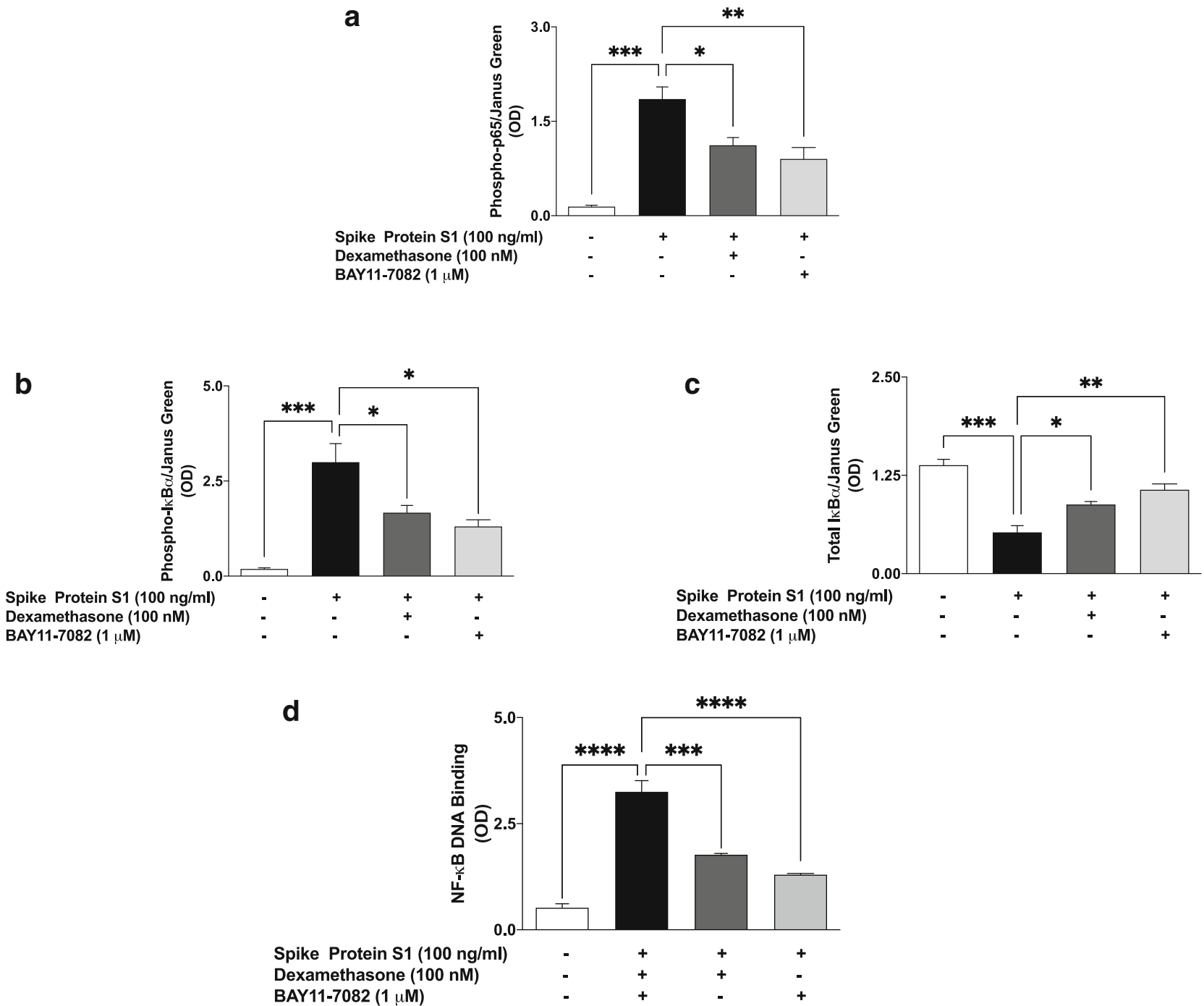

Fig. 3. Spike glycoprotein $\mathrm{S} 1(100 \mathrm{ng} / \mathrm{mL})$ stimulation of PBMCs activated NF- $\mathrm{kB}$ signalling and was inhibited by dexamethasone (100 $\mathrm{nM})$. In-cell western analyses of PBMCs revealed increased levels of phospho-p65 protein (a), phospho-IKB $\alpha(\mathbf{b})$, and a reduction in total IKB $\alpha$ protein (c) following stimulation for $15 \mathrm{~min}$. Dexamethasone pre-treatment prevented DNA binding of NF-kB following stimulation with spike glycoprotein S1 for 60 min (d). Values are mean \pm SEM for at least 3 independent experiments $(* p<0.05 ; * *<0.01 ; * * p<0.001 ; * * * p<0.0001$, compared with unstimulated control or spike glycoprotein S1 stimulation; one-way ANOVA with post-hoc Tukey’s test).

$[14,20-22]$. In fact, post-mortem analyses have revealed that high levels of pro-inflammatory cytokines are associated with cellular infiltration of organs such as the lungs, heart and kidney [14, 23, 24]. Furthermore, in a study reported by Han et al., cytokine storm characterised by increased serum levels of TNF $\alpha$ and IL- 6 were observed and suggested to be predictive of disease severity [25]. Similarly, a retrospective observational study in hospitalised patients diagnosed with
COVID-19 showed that serum levels of IL-6 greater than $30 \mathrm{pg} / \mathrm{mL}$ was a predictor of invasive mechanical ventilation requirement [26]. It is noteworthy that a similar pattern of cytokine storm was observed in preceding outbreaks such as MERS-CoV and SARS-CoV [27-30]. Pharmacological modulation of cytokine hypersecretion in coronavirus infections therefore warrants further investigation due to fatalities involving multi-organ damage. 


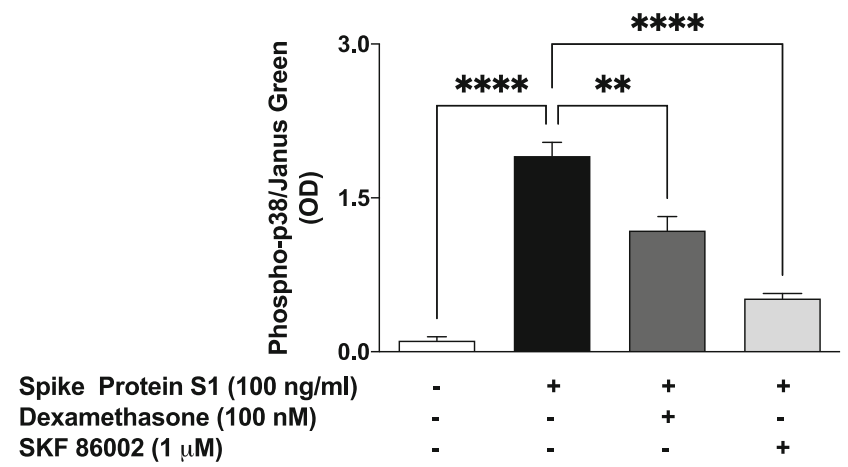

Fig. 4. Stimulation of human PBMCs with spike glycoprotein S1 $(100 \mathrm{ng} / \mathrm{mL})$ for $60 \mathrm{~min}$ activated p38 MAPK and was inhibited by treatment with dexamethasone $(100 \mathrm{nM})$ or SKF $86002(1 \mu \mathrm{M})$. Values are mean \pm SEM for at least 3 independent experiments $(* * p<0.01$; **** $p<0.0001$, compared with unstimulated control or spike glycoprotein S1 stimulation; one-way ANOVA with post-hoc Tukey's test).

Dexamethasone is a corticosteroid employed in a wide range of conditions due to its anti-inflammatory and immunosuppressant activities. However, emerging evidence suggests that dexamethasone may provide some benefits in the treatment of COVID-19. In a controlled, open-label trial conducted by the RECOVERY group, dexamethasone treatment resulted in lower 28-day mortality among COVID-19 patients who were receiving either invasive mechanical ventilation or oxygen alone [31]. Results of the CoDEX clinical trial also show that in COVID-19 with moderate or severe ARDS, the use of intravenous dexamethasone plus standard care resulted in significant improvement in clinical outcome, in comparison with standard care alone [32].

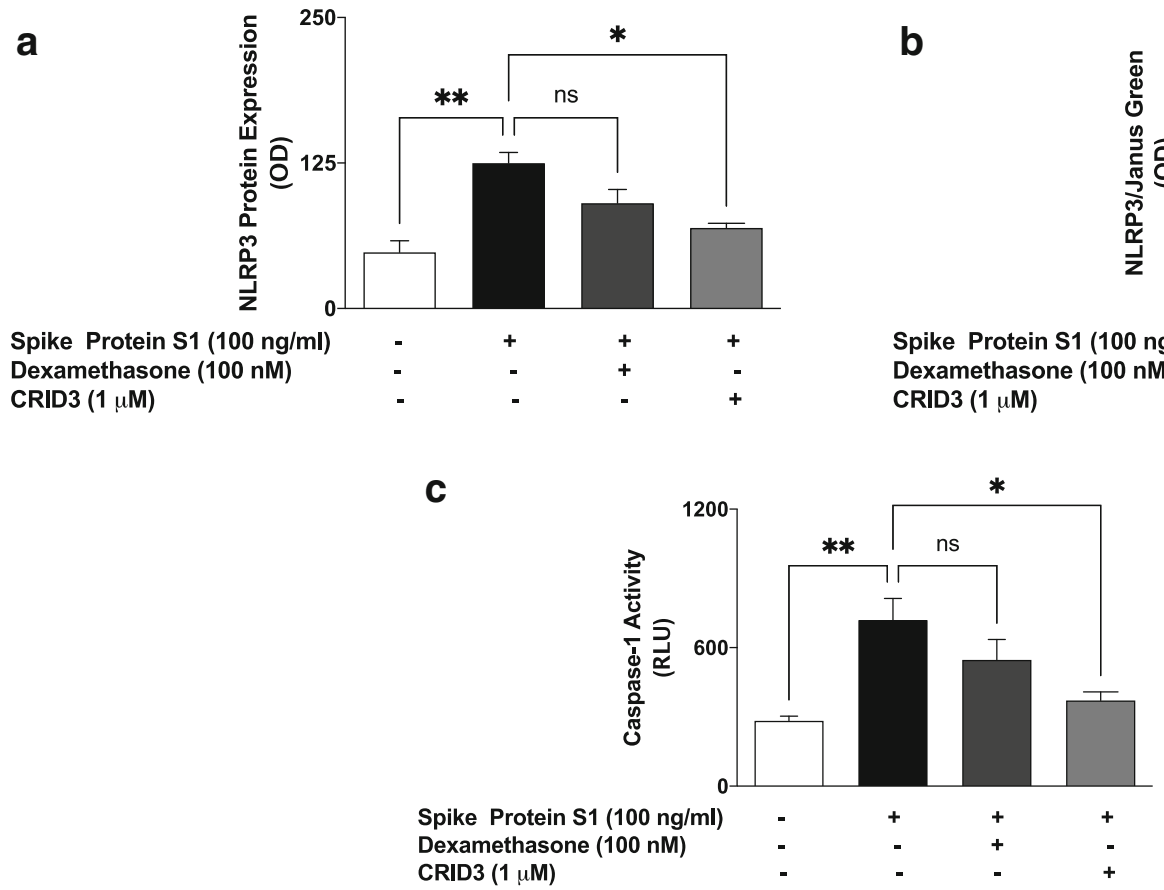

Fig. 5. Increase in protein expression of NLRP3 inflammasome following stimulation of human PBMCs with spike glycoprotein $\mathrm{S} 1$ (100 ng/mL) for $6 \mathrm{~h}$, as determined using human ELISA for NLRP3 (a) and in-cell western (b). Effects of stimulation with spike glycoprotein S1 on caspase-1 activity (c). Values are mean \pm SEM for at least 3 independent experiments (ns: not significant; ${ }^{*} p<0.05 ; * * p<0.01$, compared with unstimulated control or spike glycoprotein S1 stimulation; one-way ANOVA with post-hoc Tukey's test). 

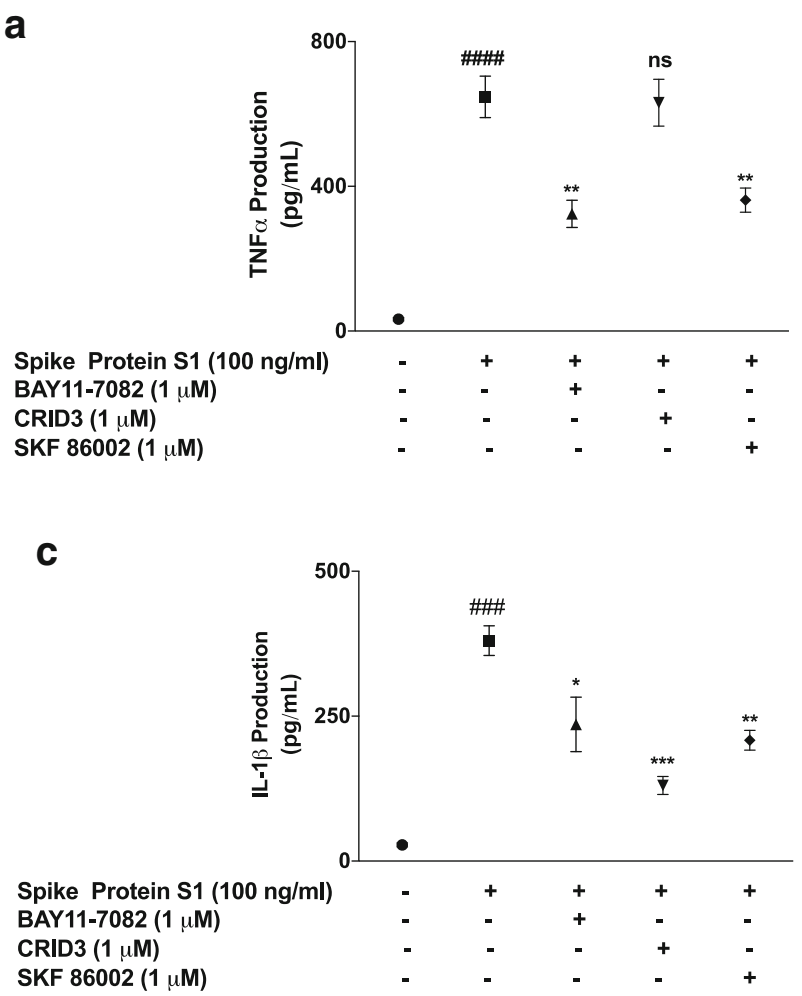
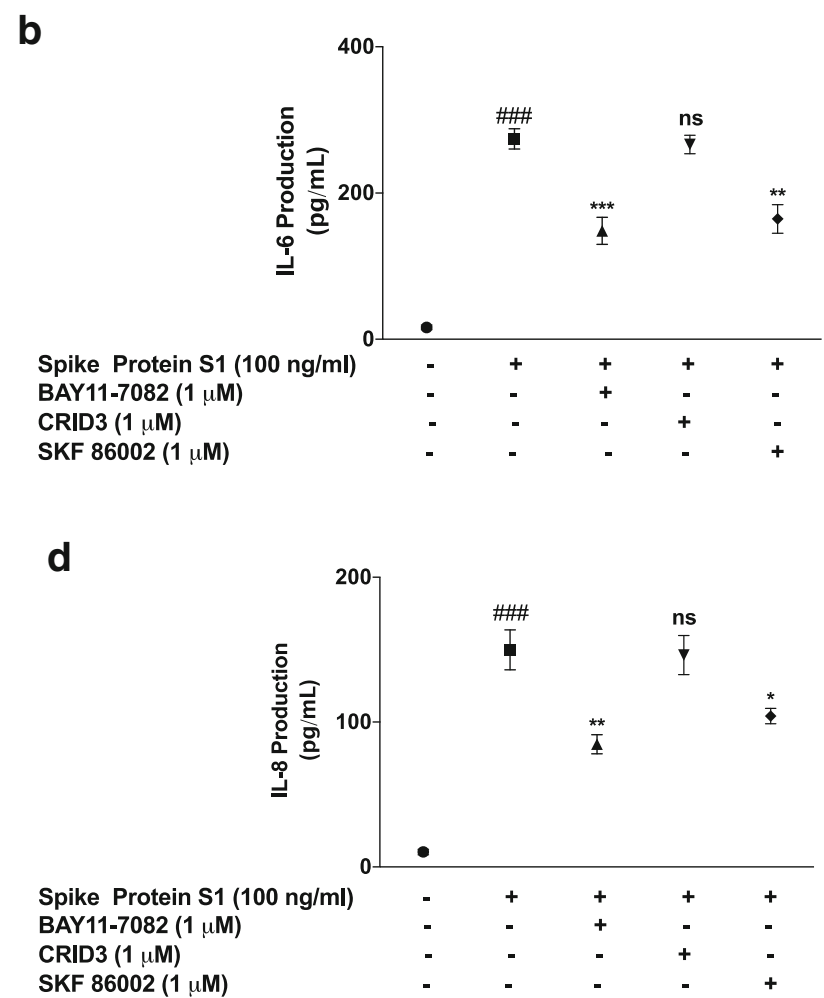

Fig. 6. Effects of pre-treatment with BAY11-7082 $(1 \mu \mathrm{M})$, SKF $86002(1 \mu \mathrm{M})$ and CRID3 $(1 \mu \mathrm{M})$ on TNF $\alpha(\mathbf{a})$, IL-6 (b), IL-1 $\beta$ (c) and IL-8 (d) production in human PBMCs. Culture supernatants were collected following stimulation for $24 \mathrm{~h}$ and analysed using human ELISA kits for TNF $\alpha$, IL-6, IL-1 $\beta$ and IL-8.

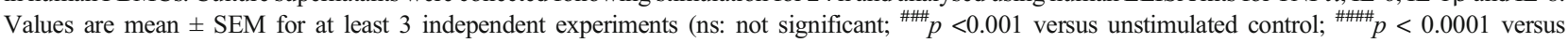
unstimulated control; * $p<0.05 ;{ }^{* *} \underline{p}<0.01 ; * * * p<0.001$, compared with spike glycoprotein S1 stimulation; one-way ANOVA with post-hoc Tukey's test).

We therefore hypothesised that the benefits of dexamethasone in treating patients with severe COVID-19 may be due in part to its antiinflammatory effect through reduction in exaggerated cytokine production at the cellular level. To prove this hypothesis, we showed that treatment with dexamethasone prevented increased production of TNF $\alpha$, IL-6, IL- $1 \beta$ and IL-8 in PBMCs stimulated with a recombinant SARS-CoV-2 spike glycoprotein S1. It appears dexamethasone blocks cellular pathways that are responsible for exaggerated production of cytokines in monocytes, macrophages and lymphocytes that are recruited following infection by SARS-CoV-2. This anti-inflammatory activity may have contributed to the overall benefits of dexamethasone in both the RECOVERY and CoDEX trials.

Dexamethasone exerts anti-inflammatory by targeting the activation of the NF- $\mathrm{KB}$ transcription factor. This drug has been shown in many studies to block
NF- $\mathrm{KB}$ activity in epithelial cells [33], as well as macrophages and monocytes [34-36]. In this study dexamethasone inhibited cytoplasmic activation, as well as DNA binding of NF- $\mathrm{KB}$ in PBMCs stimulated with SARS-CoV-2 spike glycoprotein S1, suggesting a role for the transcription factor in the reduction of proinflammatory cytokine production by dexamethasone. Our results showing a role for NF- $\mathrm{KB}$ in PBMCs seem to correlate with results of a recent study showing that SARS-CoV-2 infection of human ACE2-transgenic mice resulted in NF-kB-dependent lung inflammation [37]. Results demonstrating inhibition of SARS-CoV-2 spike glycoprotein S1-induced production of proinflammatory cytokines by BAY11-7082 further confirmed the direct involvement of NF-KB in their increased production in COVID-19 cytokine storm and warrants further investigation.

Mitogen-activated protein kinases (MAPKs) are protein kinases that regulate various cellular 
proliferation, differentiation, apoptosis, survival, inflammation and innate immunity [38, 39]. Specifically, p38 MAPK is activated by bacterial lipopolysaccharide and by pro-inflammatory cytokines and plays a major role in regulating the production of pro-inflammatory cytokines during inflammation [38-42]. Results showing increased release of pro-inflammatory cytokines by SARS-CoV-2 spike glycoprotein S1 prompted investigations which revealed an activation of p38 MAPK by the protein in PBMCs. It was further established that $\mathrm{S} 1$-induced increased cytokine production was inhibited by the p38 MAPK inhibitor, SKF86002. These observations suggest that activation of p38 MAPK is a critical contributor to hypercytokinemia in severe COVID-19. These findings appear to be consistent with the outcome of recent experiments which showed that infection of the African green monkey kidney epithelial (Vero E6) cells with the SARSCoV-2 virus resulted in the activation of $\mathrm{p} 38$ MAPK [43]. In another study reported by Bouhaddou et al., SARS-CoV-2 activation of p38 MAPK was demonstrated in ACE2-expressing A549 cells, while SARS$\mathrm{CoV}$-2-induced increase in the production of inflammatory cytokines was inhibited by another p38 inhibitor, SB203580 [44].

While this study confirmed involvement of both NF- $\mathrm{KB}$ and p38 MAPK activation in SARS-CoV-2 spike glycoprotein S1-induced exaggerated release of inflammatory cytokines in PBMCs, it is not clear if these were as a result of activation of a critical convergence upstream cellular target. The SARS-CoV-2 spike glycoprotein $\mathrm{S} 1$ is known to interact with the angiotensin-converting enzyme 2 (ACE2) receptors to gain access to host cells and has been suggested to induce immune responses. Interestingly, flow cytometry measurements of the human peripheral bloodderived immune cells revealed little or no expression of ACE2, while high expressions were reported in human tissue macrophages, such as alveolar macrophages, liver Kupffer cells, and brain microglia [45]. Other studies have reported expression of ACE2 in alveolar macrophages and human monocyte THP-1 cells [46]. Studies to further determine the roles of ACE2 in spike glycoprotein S1-induced inflammation are therefore needed. The unresolved roles of ACE2 in this respect will stimulate interest in the potential roles of toll-like receptors (TLRs) in the induction of exaggerated cytokine release by SARS-CoV-2 spike glycoprotein S1. Results of observational studies by Sohn et al. [47] revealed that TLR4 and its inflammatory signalling molecules were upregulated in PBMCs from COVID-19 patients, compared with healthy controls. These results, coupled with our data suggest that the SARS-CoV-2 spike glycoprotein S1, appear to be activating NF- $\mathrm{KB}$ and $\mathrm{p} 38$ MAPK signalling through activation of TLR4.

Our investigations further revealed that the spike protein S1 increased NLRP3 protein expression as well as caspase-1 activity in PBMCs, which may be contributing to the release of IL-1 $\beta$ by these cells. Interestingly, the activation of NLRP3/caspase- 1 by S1 was not significantly reduced by dexamethasone, showing that the effects of the drug may be more pronounced on NF-KB signalling in these cells. Targeting of the NLRP3 inflammasome activation pathway in macrophages has been suggested as one of the mechanisms involved in SARS-CoV-2 cytokine storm $[15,48]$. With data from studies suggesting that the spike protein S1 could be activating TLR4 to cause macrophage-mediated cytokine storm, coupled with our data showing activation of NLRP3 inflammasome by the protein, further investigations need to confirm TLR-mediated activation of NLRP3 inflammasome by the protein.

The studies reported here have shown that the SARS-CoV-2 spike glycoprotein S1 induced exaggerated inflammation in PBMCs through mechanisms involving activation of NF- $\mathrm{kB}$ transcription factor, $\mathrm{p} 38$ MAPK and the NLRP3 inflammasome. It is proposed that the clinical benefits of dexamethasone in severe COVID-19 are possibly due to its anti-inflammatory activity in reducing SARS-CoV-2 cytokine storm and subsequent multi-organ failure. It is further proposed that S1-induced production of cytokines in human peripheral blood mononuclear cells is a potential cellular model to investigate anti-inflammatory compounds for reducing cytokine storm in SARS-CoV-2 infection. Further studies will focus on the possible interactions between the spike glycoprotein S1 and toll-like receptors in the activation of cellular immune response.

\section{AUTHOR CONTRIBUTION}

Olumayokun A Olajide: Conceptualisation; methodology; investigation; writing, original draft; writing, review and editing; project administration. Victoria $U$ Iwuanyanwu: investigation. Izabela Lepiarz-Raba: investigation. Alaa Al-Hindawi: investigation. 


\section{DECLARATIONS}

\author{
Research Involving Human Participants and/or Ani- \\ mals. Not applicable.
}

Informed Consent. Not applicable.

Consent to Participate. Not applicable.

Consent for Publication. Not applicable.

Conflict of Interest. All authors certify that they have no affiliations with or involvement in any organization or entity with any financial interest or non-financial interest in the subject matter or materials discussed in this manuscript.

Open Access This article is licensed under a Creative Commons Attribution 4.0 International License, which permits use, sharing, adaptation, distribution and reproduction in any medium or format, as long as you give appropriate credit to the original author(s) and the source, provide a link to the Creative Commons licence, and indicate if changes were made. The images or other third party material in this article are included in the article's Creative Commons licence, unless indicated otherwise in a credit line to the material. If material is not included in the article's Creative Commons licence and your intended use is not permitted by statutory regulation or exceeds the permitted use, you will need to obtain permission directly from the copyright holder. To view a copy of this licence, visit http://creativecommons.org/licenses/by/4.0/.

\section{REFERENCES}

1. Zhu, N., D. Zhang, W. Wang, X. Li, B. Yang, J. Song, X. Zhao, B. Huang, W. Shi, R. Lu, P. Niu, F. Zhan, X. Ma, D. Wang, W. Xu, G. Wu, G.F. Gao, W. Tan, and China Novel Coronavirus Investigating and Research Team. 2020. A novel coronavirus from patients with pneumonia in China 2019. The New England Journal of Medicine 382: 727-733.

2. Zhou, P., X.L. Yang, X.G. Wang, B. Hu, L. Zhang, W. Zhang, H.R. Si, Y. Zhu, B. Li, C.L. Huang, H.D. Chen, J. Chen, Y. Luo, H. Guo, R.D. Jiang, M.Q. Liu, Y. Chen, X.R. Shen, X. Wang, X.S. Zheng, K. Zhao, Q.J. Chen, F. Deng, L.L. Liu, B. Yan, F.X. Zhan, Y.Y. Wang, G.F. Xiao, and Z.L. Shi. 2020. A pneumonia outbreak associated with a new coronavirus of probable bat origin. Nature 579: $270-273$.
3. Novel Coronavirus (2019-nCoV) situation reports - World Health Organization (WHO)

4. Huang, C., Y. Wang, X. Li, L. Ren, J. Zhao, Y. Hu, L. Zhang, G. Fan, J. Xu, X. Gu, Z. Cheng, T. Yu, J. Xia, Y. Wei, W. Wu, X. Xie, W. Yin, H. Li, M. Liu, Y. Xiao, H. Gao, L. Guo, J. Xie, G. Wang, R. Jiang, Z. Gao, Q. Jin, J. Wang, and B. Cao. 2020. Clinical features of patients infected with 2019 novel coronavirus in Wuhan, China. Lancet. 395: 497-506.

5. Moradian, N., M. Gouravani, M.A. Salehi, A. Heidari, M. Shafeghat, M.R. Hamblin, and N. Rezaei. 2020. Cytokine release syndrome: inhibition of pro-inflammatory cytokines as a solution for reducing COVID-19 mortality. European Cytokine Network 31: 8193.

6. Hirawat, R., M.A. Saifi, and C. Godugu. 2020. Targeting inflammatory cytokine storm to fight against COVID-19 associated severe complications. Life Sciences 267: 118923.

7. Yang, L., S. Liu, J. Liu, Z. Zhang, X. Wan, B. Huang, Y. Chen, and Y. Zhang. 2020. COVID-19: immunopathogenesis and Immunotherapeutics. Signal Transduction and Targeted Therapy 5: 128.

8. Lee, C., and W.J. Choi. 2021. Overview of COVID-19 inflammatory pathogenesis from the therapeutic perspective. Archives of Pharmacal Research 4: 1-18.

9. Grifoni, E., A. Valoriani, F. Cei, R. Lamanna, A.M.G. Gelli, B. Ciambotti, V. Vannucchi, F. Moroni, L. Pelagatti, R. Tarquini, G. Landini, S. Vanni, and L. Masotti. 2020. Interleukin-6 as prognosticator in patients with COVID-19. The Journal of Infection 81: 452-482.

10. Aziz, M., R. Fatima, and R. Assaly. 2020. Elevated interleukin-6 and severe COVID-19: a meta-analysis. Journal of Medical Virology 92: 2283-2285.

11. Ahmed, S.F., A.A. Quadeer, and M.R. McKay. 2020. Preliminary identification of potential vaccine targets for the COVID-19 coronavirus (SARS-CoV-2) based on SARS-CoV immunological studies. Viruses. 12: 254

12. Catanzaro, M., F. Fagiani, M. Racchi, E. Corsini, S. Govoni, and C. Lanni. 2020. Immune response in COVID-19: addressing a pharmacological challenge by targeting pathways triggered by SARSCoV-2. Signal Transduction and Targeted Therapy 5: 84.

13. Giamarellos-Bourboulis, E.J., M.G. Netea, N. Rovina, et al. 2020. Complex immune dysregulation in COVID-19 patients with severe respiratory failure. Cell Host \& Microbe 27: 992-1000.e3.

14. Merad, M., and J.C. Martin. 2020. Pathological inflammation in patients with COVID-19: a key role for monocytes and macrophages. Nature Reviews. Immunology 20: 355-362.

15. Freeman, T.L., and T.H. Swartz. 2020. Targeting the NLRP3 Inflammasome in Severe COVID-19. Frontiers in Immunology 11: 1518 .

16. Walls, A.C., Y.J. Park, M.A. Tortorici, A. Wall, A.T. McGuire, and D. Veesler. 2020. Structure, function, and antigenicity of the SARSCoV-2 spike glycoprotein. Cell 181: 281-292.e6.

17. Duan, L., Q. Zheng, H. Zhang, Y. Niu, Y. Lou, and H. Wang. 2020. The SARS-CoV-2 spike glycoprotein biosynthesis, structure, function, and antigenicity: implications for the design of spike-based vaccine immunogens. Frontiers in Immunology 11: 576622.

18. Velagapudi, R., I. Lepiarz, A. El-Bakoush, F.O. Katola, H. Bhatia, B.L. Fiebich, and O.A. Olajide. 2019. Induction of autophagy and activation of SIRT-1 deacetylation mechanisms mediate neuroprotection by the pomegranate metabolite urolithin $\mathrm{A}$ in $\mathrm{BV} 2$ microglia and differentiated 3D human neural progenitor cells. Molecular Nutrition \& Food Research 63: e1801237.

19. Olajide, O.A., I.S. Akande, C. da Silva Maia Bezerra Filho, I. Lepiarz-Raba, and D.P. de Sousa. 2020. Methyl 3,4,5-trimethoxycinnamate suppresses inflammation in RAW264.7 macrophages and 
blocks macrophage-adipocyte interaction. Inflammopharmacology. 28: $1315-1326$.

20. Chen, G., D. Wu, W. Guo, Y. Cao, D. Huang, H. Wang, T. Wang, X. Zhang, H. Chen, H. Yu, X. Zhang, M. Zhang, S. Wu, J. Song, T. Chen, M. Han, S. Li, X. Luo, J. Zhao, and Q. Ning. 2020. Clinical and immunological features of severe and moderate coronavirus disease 2019. The Journal of Clinical Investigation 130: 2620-2629.

21. Qin, C., L. Zhou, Z. Hu, S. Zhang, S. Yang, Y. Tao, C. Xie, K. Ma, K. Shang, W. Wang, and D.S. Tian. 2020. Dysregulation of immune response in patients with coronavirus 2019 (COVID-19) in Wuhan, China. Clinical Infectious Diseases 71: 762-768.

22. Gong, J., H. Dong, Q.S. Xia, Z.Y. Huang, D.K. Wang, Y. Zhao, W.H. Liu, S.H. Tu, M.M. Zhang, Q. Wang, and F.E. Lu. 2020. Correlation analysis between disease severity and inflammationrelated parameters in patients with COVID-19: a retrospective study. BMC Infectious Diseases 20: 963.

23. Xu, Z., L. Shi, Y. Wang, J. Zhang, L. Huang, C. Zhang, S. Liu, P. Zhao, H. Liu, L. Zhu, Y. Tai, C. Bai, T. Gao, J. Song, P. Xia, J. Dong, J. Zhao, and F.S. Wang. 2020. Pathological findings of COVID-19 associated with acute respiratory distress syndrome. The Lancet Respiratory Medicine 8: 420-422.

24. Mustafa, M.I., A.H. Abdelmoneim, E.M. Mahmoud, and A.M. Makhawi. 2020. Cytokine storm in COVID-19 patients, its impact on organs and potential treatment by QTY code-designed detergentfree chemokine receptors. Mediators of Inflammation 2020: 8198963.

25. Han, H., Q. Ma, C. Li, R. Liu, L. Zhao, W. Wang, P. Zhang, X. Liu, G. Gao, F. Liu, Y. Jiang, X. Cheng, C. Zhu, and Y. Xia. 2020. Profiling serum cytokines in COVID-19 patients reveals IL-6 and IL-10 are disease severity predictors. Emerging Microbes and Infection 9: 1123-1130.

26. Galván-Román, J.M., S.C. Rodríguez-García, E. Roy-Vallejo, et al. 2021. IL-6 serum levels predict severity and response to tocilizumab in COVID-19: an observational study. The Journal of Allergy and Clinical Immunology 147: 72-80.e8.

27. Mahallawi, W.H., Khabour OF, Q. Zhang, H.M. Makhdoum, and B.A. Suliman. 2018. MERS-CoV infection in humans is associated with a pro-inflammatory Th1 and Th17 cytokine profile. Cytokine. 104: 8-13.

28. Wong, C.K., C.W. Lam, A.K. Wu, et al. 2004. Plasma inflammatory cytokines and chemokines in severe acute respiratory syndrome. Clinical and Experimental Immunology 136: 95-103.

29. Channappanavar, R., and S. Perlman. 2017. Pathogenic human coronavirus infections: causes and consequences of cytokine storm and immunopathology. Seminars in Immunopathology 39: 529539.

30. Lau, S.K.P., C.C.Y. Lau, K.H. Chan, C.P.Y. Li, H. Chen, D.Y. Jin, J.F.W. Chan, P.C.Y. Woo, and K.Y. Yuen. 2013. Delayed induction of proinflammatory cytokines and suppression of innate antiviral response by the novel Middle East respiratory syndrome coronavirus: implications for pathogenesis and treatment. The Journal of General Virology 94: 2679-2690.

31. RECOVERY Collaborative Group, Horby P, Lim WS, Emberson JR, Mafham M, Bell JL, Linsell L, Staplin N, Brightling C, Ustianowski A, Elmahi E, Prudon B, Green C, Felton T, Chadwick D, Rege K, Fegan C, Chappell LC, Faust SN, Jaki T, ... Landray MJ (2021) Dexamethasone in hospitalized patients with Covid-19. The New England Journal of Medicine 384:693-704.

32. Tomazini, B.M., I.S. Maia, A.B. Cavalcanti, O. Berwanger, R.G. Rosa, V.C. Veiga, A. Avezum, R.D. Lopes, F.R. Bueno, M.V.A.O. Silva, F.P. Baldassare, E.L.V. Costa, R.A.B. Moura, M.O. Honorato, A.N. Costa, L.P. Damiani, T. Lisboa, L. Kawano-Dourado, F.G. Zampieri, G.B. Olivato, C. Righy, C.P. Amendola, R.M.L.
Roepke, D.H.M. Freitas, D.N. Forte, F.G.R. Freitas, C.C.F. Fernandes, L.M.G. Melro, G.F.S. Junior, D.C. Morais, S. Zung, F.R. Machado, L.C.P. Azevedo, and COALITION COVID-19 Brazil III Investigators. 2020. Effect of dexamethasone on days alive and ventilator-free in patients with moderate or severe acute respiratory distress syndrome and COVID-19: the CoDEX randomized clinical trial. JAMA. 324: 1307-1316.

33. Newton, R., L.A. Hart, D.A. Stevens, M. Bergmann, L.E. Donnelly, I.M. Adcock, and P.J. Barnes. 1998. Effect of dexamethasone on interleukin-1beta-(IL-1beta)-induced nuclear factor-kappaB (NFkappaB) and kappaB-dependent transcription in epithelial cells. European Journal of Biochemistry 254: 81-89.

34. Jeon, Y.J., S.H. Han, Y.W. Lee, M. Lee, K.H. Yang, and H.M. Kim. 2000. Dexamethasone inhibits IL-1 beta gene expression in LPSstimulated RAW 264.7 cells by blocking NF-kappa B/Rel and AP-1 activation. Immunopharmacology. 48: 173-183.

35. Fong, C.C., Y. Zhang, Q. Zhang, C.H. Tzang, W.F. Fong, R.S.S. Wu, and M. Yang. 2007. Dexamethasone protects RAW264.7 macrophages from growth arrest and apoptosis induced by $\mathrm{H} 2 \mathrm{O} 2$ through alteration of gene expression patterns and inhibition of nuclear factor-kappa B (NF-kappaB) activity. Toxicology. 236: $16-28$.

36. Kim, B.Y., Y. Son, J. Lee, J. Choi, C.D. Kim, S.S. Bae, S.K. Eo, and K. Kim. 2017. Dexamethasone inhibits activation of monocytes/ macrophages in a milieu rich in 27-oxygenated cholesterol. PLoS One 12: $\mathrm{e} 0189643$.

37. Winkler, E.S., A.L. Bailey, N.M. Kafai, S. Nair, B.T. McCune, J. Yu, J.M. Fox, R.E. Chen, J.T. Earnest, S.P. Keeler, J.H. Ritter, L.I. Kang, S. Dort, A. Robichaud, R. Head, M.J. Holtzman, and M.S. Diamond. 2020. SARS-CoV-2 infection of human ACE2-transgenic mice causes severe lung inflammation and impaired function. $\mathrm{Na}$ ture Immunology 21: 1327-1335.

38. Arthur, J.S., and S.C. Ley. 2013. Mitogen-activated protein kinases in innate immunity. Nature Reviews. Immunology 13: 679-692.

39. Kim, E.K., and E.J. Choi. 2015. Compromised MAPK signaling in human diseases: an update. Archives of Toxicology 89: 867-882.

40. Lee, J.C., J.T. Laydon, P.C. McDonnell, et al. 1994. A protein kinase involved in the regulation of inflammatory cytokine biosynthesis. Nature. 372: 739-746.

41. Cuenda, A., and S. Rousseau. 2007. p38 MAP-kinases pathway regulation, function and role in human diseases. Biochimica et Biophysica Acta 1773: 1358-1375.

42. Sabio, G., and R.J. Davis. 2014. TNF and MAP kinase signalling pathways. Seminars in Immunology 26: 237-245.

43. Ma, Q., W. Pan, R. Li, B. Liu, C. Li, Y. Xie, Z. Wang, J. Zhao, H. Jiang, J. Huang, Y. Shi, J. Dai, K. Zheng, X. Li, and Z. Yang. 2020. Liu Shen capsule shows antiviral and anti-inflammatory abilities against novel coronavirus SARS-CoV-2 via suppression of NF-kB signaling pathway. Pharmacological Research 158: 104850.

44. Bouhaddou, M., D. Memon, B. Meyer, et al. 2020. The global phosphorylation landscape of SARS-CoV-2 infection. Cell 182: 685-712.e19.

45. Song, X., W. Hu, H. Yu, L. Zhao, Y. Zhao, X. Zhao, H.H. Xue, and Y. Zhao. 2020. Little to no expression of angiotensin-converting enzyme-2 on most human peripheral blood immune cells but highly expressed on tissue macrophages. Cytometry. Part A. https://doi.org/ 10.1002/cyto.a.24285.

46. Duan F, Guo L, Yang L, et al. (2020) Modeling COVID-19 with human pluripotent stem cell-derived cells reveals synergistic effects of anti-inflammatory macrophages with ace 2 inhibition against SARS-CoV-2. Res Sq [Preprint]. rs.3.rs-62758. https://doi.org/ 10.21203/rs.3.rs-62758/v1. 
47. Sohn, K.M., S.G. Lee, H.J. Kim, S. Cheon, H. Jeong, J. Lee, I.S. Kim, P. Silwal, Y.J. Kim, S. Paik, C. Chung, C. Park, Y.S. Kim, and E.K. Jo. 2020. COVID-19 patients upregulate toll-like receptor 4mediated inflammatory signaling that mimics bacterial sepsis. Journal of Korean Medical Science 35: e343.

48. Rodrigues, T.S., K.S.G. de Sá, A.Y. Ishimoto, A. Becerra, S. Oliveira, L. Almeida, A.V. Gonçalves, D.B. Perucello, W.A. Andrade, R. Castro, F.P. Veras, J.E. Toller-Kawahisa, D.C. Nascimento, M.H.F. de Lima, C.M.S. Silva, D.B. Caetite, R.B. Martins, I.A.
Castro, M.C. Pontelli, F.C. de Barros, N.B. do Amaral, M.C. Giannini, L.P. Bonjorno, M.I.F. Lopes, R.C. Santana, F.C. Vilar, M. Auxiliadora-Martins, R. Luppino-Assad, S.C.L. de Almeida, F.R. de Oliveira, S.S. Batah, L. Siyuan, M.N. Benatti, T.M. Cunha, J.C. Alves-Filho, F.Q. Cunha, L.D. Cunha, F.G. Frantz, T. Kohlsdorf, A.T. Fabro, E. Arruda, R.D.R. de Oliveira, P. Louzada-Junior, and D.S. Zamboni. 2021. Inflammasomes are activated in response to SARS-CoV-2 infection and are associated with COVID-19 severity in patients. The Journal of Experimental Medicine 218: e20201707. 